\title{
Tourism Planning and Impediments to the Development of the Tourism Sector in Jordan
}

\author{
Issam Mohammad Al-makhadmah \\ Tourism Management Department, Ajloun College, Al-Balqa Applied University, Jordan
}

PO box 26826, Ajloun, Jordan

Khalid Mohammed Alarabaah

Department of planning, Training, and Quality, Ajloun College, Al-Balqa Applied University, Jordan

PO box 26826, Ajloun, Jordan

Ababneh Samer Fandi*

School of Administrative and Finance Sciences (Department of Tourism), Balqa University of Jordan

PO box 26826, Ajloun, Jordan.

The research is financed by Asian Development Bank. No. 2006-A171(Sponsoring information)

\section{Abstract}

The study aimed at identifying the level of tourism planning impediments to the development of the tourism sector in Jordan. To achieve the objectives of the study, the descriptive analytical approach was used and a questionnaire was prepared to collect data after verifying their validity and stability. The study sample consisted of 500 employees (male/female) of the tourism sector (public and private) in Jordan. The results showed that the level of planning in the Jordanian tourism sector was at the average. While the level of impediments (environmental, organizational, administrative and media) to the development of the tourism sector in Jordan was high, Also, the results showed that the level of impediment (social, service and political) to develop the tourism sector in Jordan at the averaged. The most prominent of these impediments is poverty, which is one of the causes of environmental degradation to carry out destructive practices of the environment such as overgrazing, logging, and the lack of some entertainment projects at tourist facilities to attract tourists and families.

Keywords: Tourism Planning, Impediments, Development, Tourism Sector, Jordan.

DOI: $10.7176 / \mathrm{JTHS} / 48-04$

Publication date:March $31^{\text {st }} 2020$

\section{Introduction}

The interest in tourism planning led to the advent of tourism, especially after the Second World War, that governments and organizations pay attention to the development of international travel and increase the diversity of forms of tourism that are local and global, or are single-purpose or multi-objective or vary in duration (Abdelkader, 2006).

Tourism planning is one of the vital processes for developing tourism and facing change that can only be achieved through careful planning and careful follow-up. Tourism planning is linked to the tourism sector in facing negative variables and benefiting from the positive variables and employing and exploiting them (Qasymh, 2010).

Tourism planning shows its relationship with the tourism sector as it serves as a tool for achieving coordination between the different sectors that work to maximize the positive effects of tourism development and mitigate its negative effects. The development of tourist areas requires the comprehensive planning of different economic sectors taking into consideration the positive and negative effects of development (Qasymh, 2010).

It is also considered one of the main sources of national income in addition to the comprehensive cultural development of all natural, human and material components. Hence, tourism development is a means of economic development (Bzazu, 2012).

Tourism is one of the most important economic pillars that increase its importance in the growing of the material income as it is an important source of national income. The transport and tourism sector contributes to develop the material and service sectors of the society, which facilitates the development of these vital sources and benefiting from the tourism sector (Na'as, 2009).

e means of transport constitute a basic and active support for tourism activities, where they exchange the spatial processes of resources and people and ensure the various requirements of movement within the study sector. Therefore, it achieves material benefits, enhances its importance and increases its investment level (Na'as, 2009).

Interest in investments in developing countries has led to increased economic and social development to raise self-sufficiency ratios. Therefore, the development of tourism in other areas of development is especially important because Jordan has a diverse base of tourism, whether it is religious tourism, health, climate or sports. However, investment in tourism requires a large amount of capital due to the high cost of Infrastructure and Equipment (Jalila, 2000). 
Governments play an important role in promoting tourism growth and enhancing the role of national tourism organizations by formulating the necessary tourism legislation in developing countries and providing incentives to finance some tourist projects and giving attention to tourist infrastructure. By law, an investment promotion organization called "The main investment promotion organization for the government sector" was established as a tourism investment (Jenkins, 1994).

It is also noted that the tourism income between 1997 and 1998 increased by more than 6\% in Jordan, according to the reports of the World Tourism Organization. The tourism activities also witnessed a remarkable development during the past years, which helped to encourage and attract tourism investments. The share of Jordan was $13.1 \%$

\section{Problem of the study}

The tourism sector is one of the most important sectors, accounting for 13\% of Jordan GDP and revenues of about 4.3 billion dollars annually. Where the number of tourists in Jordan in 2014 about (5.3) million tourists from around the world, in addition; Jordan is considered one of the most important tourist attractions in the Middle East. It is mainly due to its religious, historical and strategic importance. Also it has other characteristics that make it a destination for tourists and visitors from all over the world throughout the year, especially since it is considered the fifth country in terms of medical tourism. There are also some impediments and problems facing the tourism sector, which limit its development significantly, in addition to neglect, low quality, difficult transport and the lack of legislation still exist and constitute a major impediments to the development of the tourism sector. To solve this problem, the researcher formulated the problem in the following questions:

1. What is the level of planning in the Jordanian tourism sector?

2. What are the impediments to development (SOA, environmental, organizational, administrative, media, social and political) to develop the tourism sector in Jordan?

3. Is the level of planning of development impediments in the Jordanian tourism sector different depending on the variables (type of sector, gender, job category, qualification, experience, monthly income)?

\section{Heading Aims of the study}

This study aims at identifying the level of tourism planning and identifying the impediments of development (service, environment, organizational, administrative, media, social and political) to develop the tourism sector in Jordan.

\section{The importance of the study}

The World Tourism Organization (1995-2020)estimates that the number of arrivals will rise to 2.5 times during the period, ie, 1.6 billion people at an annual rate of increase $(4.1 \%)$. It is expected that the receipts of tourism in 2020 will reach about $\$ 2000$ billion, while noting that the share of Arab countries in the movement of arrivals (68.5) million people, an average annual increase (7.1\%) for the same period, which Indicates the future importance of the tourism sector globally and the Arab world on the one hand and the challenges facing the Arab world in the future on the other hand.

The importance of the research shows that the tourism sector in Jordan highlights the importance of developing the tourism sector and its role in encouraging tourism in addition to trying to identify the impediments that are prevented the development of the tourism sector in Jordan based on the tourist planning approach to try to overcome these impediments and work on developing the tourism sector in Jordan.

This study highlighted the importance of tackling the most serious issue among contemporary economic and social issues. It dealt with the obstacles to tourism development in Jordan, especially in the security and economic crises. This issue affects the tourism sector in Jordan. Directly or indirectly, this issue occupies an important place at the levels of domestic and foreign policy of the state because tourism is an important and essential source of hard currency.

\section{Terms of the study}

Planning: It is a systematic and ongoing scientific means by which the needs of society are assessed by limiting the available material resources (Abdelkader, 2006).

Tourism planning: An organizational approach aimed at achieving economic and social development over a defined period of time by limiting the potential of the tourism community and using it towards achieving the society's goals and social philosophy (Ahmad, 2011).

Tourism Development: Providing facilities and services to meet the needs and desires of tourists, and also includes some of the effects of tourism, such as: creating new employment opportunities and new incomes. Tourism development includes all aspects related to spatial patterns of tourism supply and demand and Geographical distribution of tourism products, 2004).

Organizational impediments: Factors that lead to deviation from the ideal model of development and prevent the 
attainment of the objectives pursued by local organization (Mustafa, 2005).

\section{Theoretical background}

Tourism planning is one of the branches of economic planning in which the set of phased actions and methodological procedures are carried out, thus providing the material and moral requirements to achieve the optimal exploitation of the tourist attractions available to achieve maximum benefit from the tourism sector (Othman, 2017).

\subsection{Importance of tourism planning}

Tourism planning plays an important role in the development of tourism activity because it provides a common framework for decision-making in the management of tourism resources by following the scientific method to organize and manage tourist activity in all its elements and patterns. It also serves the responsible bodies in the methods and directions that can be followed and the availability of funds and efforts. (Al-Mashhadani, 2016).

Tourism planning is based on the implementation of tourism policies according to a program that is based on a long or short term steps, in addition to defining the goals of the plan in order to achieve tourism development. Furthermore; tourism planning is not limited to official bodies, as well as includes sectors, individuals and workers in the tourism services sector. Therefore, the sectors are encouraged to invest the tourist facilitation sits by the financial support, whether internal or external, and providing public services as intended in tourist sits in order to develop scientific procedures which are suitable for the environmental preservation (Al-Wadi, 2010).

\subsection{Objectives of tourism planning}

Tourism planning is based on the implementation of tourism policies to be implemented according to a program based on steps in the long or near term. The objectives of the plan are not limited to the development of tourism and tourism planning to the official bodies, but include sectors, individuals and employees in the tourism services sector; this encourages sectors to invest in tourist facilities, through the provision of financing, whether internal or external, and the provision of public services as required in the tourist areas in order to develop scientific procedures suitable for the preservation of the environment (Alwadi, 2010).

\subsection{The stages of preparing the tourism development plan}

The process of preparation of the development plan is based on the serial steps based on the preparation of preliminary studies to determine the initial goals so that they can be modified if we need them through feedback and then all the information that is conducted by the surveys to assess the situation of the tourist area and then the process of analysis of data and interpretation to come out with facts that help Preparing the plan that helps the policies to choose the appropriate programs and projects to implement them and achieve the objectives of the plan ,then implement the plan by means of its recommendations and follow up the tourism plan according to the feedback system (Dulaimi, 2005).

\subsection{Objectives of Tourism Development}

Tourism development seeks to achieve a balanced increase in tourism resources and to consider human resources as the first important axis of tourism resources. The process of tourism development requires finding new areas that tourists may attract in order to make a comparison with the tourism products of the competitive countries and rely on the characteristics of world tourism demand which is considered the basis for creating the infrastructure and national tourism by encouraging tourism investment and facilitating the investment process (Malukhia, 2007). The process of developing tourist activity requires cooperation in all elements, possibilities and efforts that work in the tourism sector because tourism includes many facilities and various economic activities. Therefore, the planning process for tourism development aims to develop programs to use tourist places and resources and then develop them to attract tourists (Saad, 2008).

\subsection{The Impact of tourism planning in tourism development}

The impact of tourism planning on the levels of tourism development, especially environmental and urban impact, Which helps tourism to achieve optimum utilization of natural resources in order to preserve them. It also organizes and modernizes the land uses in a way that maximizes the benefit. These include (preserving urban policies and improving the quality of the environment), In addition to the social and cultural impact, which calls for tourism to learn the cultures of different peoples through communication and social mobility with each other in tourist areas, thus increasing mutual understanding and respect and the convergence of values and customs (preservation of architectural patterns and historical and cultural heritage, and revival of traditional industries and traditional events) (Increased foreign and national investment), the marketing of certain goods, the creation of jobs and the solution of unemployment problems (Diab, 2015). 


\subsection{Impediments to the development of tourism}

There are several Impediments for tourism (Na'as, 2009):

1. Social and political obstacle impediments: Tourism is an important economic component because it is one of the social factors that control the interaction of tourists and this requires direct contact between them, and that the cultural level and social awareness determine the method of dealing which is a factor to attract tourists and avoid a fortress and fear of contact with others because of customs and traditions, which prevents tourists from communicating and cooperation between them or may be issued some of the behavior of people who work in restaurants and hotels in tourist facilities some harassment and inconveniences Which touched on the feelings of tourism, pointing out that political conditions and unstable conditions in the decline of tourism.

2. The organizational, administrative and media impediments: Tourism is of a more rapid nature with social and economic variables. The prices of the tourist market sometimes lead to the handicap of cities and regions, in addition to the high prices of materials, goods, accommodation costs and hotels. The set of administrative decisions and instructions issued by the competent authorities also affect the direction of tourism investment operations, while it may cause a clear handicap that affects the fees and taxes on tourism projects. It also imposes on the importation of building materials, equipment and equipment from transportation means. On the other hand, the low level of entertainment and marketing activities and marketing festivals in most cases. Government administrative authorities also require the closure of streets and shops in the summer, in addition, advertising activities to promote tourism are considered an important source of tourism attraction that has not been exploited greatly and used in domestic tourism advertising more than the outside.

3. Impediment services: infrastructure services is an important element in meeting the tourism needs of restaurants, hotels, cafes and places of entertainment and leisure as well as means of transport, public services, cleaning services, water, electricity and sanitation, in addition to the lack of places specialized private parking for tourists.

4. Environmental Impediment: Environmental constraints lead to environmental damage, such as encroachment on the natural environment and its vital components such as air, water and vegetation, as well as slow traffic due to the parking on both sides of the main roads in front of shops and the narrow sidewalks for tourists. Resulting from the movement of cars and some devices are also manifestations of pollution for tourist facilities, urban and service through the disposal of waste produced by the population areas.

\subsection{Previous studies}

This research deals with a series of previous studies related to the variables of this study in Jordanian and global studies.

Osman (2017), identifies tourism planning as a tool for the development of archeological and religious tourism in the city of Samarra. He dealt with the practical use of the planning process and the possibility of using tourism planning by the local government, scientific and research institutions and businessmen for the development of tourism sector. The researcher used the analytical descriptive approach in addition to the historical method through analyzing the chronological events that influenced the tourism sector and presented it in an academic way. The results show that the city of Samarra is characterized by many tourist elements that help to build a distinctive tourist sector, such as holy shrines and archaeological and historical centers.

As for bajawih (2015) identifies tourism planning as a tool for achieving development. The study used the analytical descriptive method by diagnosing the tourism sector, giving a clear picture of it, find out the pros and cons, and using a set of tools such as tourism data and statistics provided by the World Tourism Organization. The number of international tourists arrivals increased by $40 \%$ in the first four months of 2015 . One of the most important results is the adoption of a comprehensive development strategy for its tourism sector with a horizon until 2030 to aspire to achieve sustainable tourism development in Algeria and to make it a global tourist attraction with a high competitive attractiveness.

Samardali (2013) conducted a study aimed at exploring the importance of obstacles to the development of tourism in Jordan. This research will give the Jordan Tourism Board an opportunity to improve the tourism sector and generate increased revenues to promote Jordan as a tourist destination, domestically and internationally. At the time of this study, there was no strong evidence to suggest that stakeholder organizations were working together to overcome obstacles. In addition, Jordan's communities felt justified in increasing prices in tourist attractions, causing tourists to feel exploited and thus keeping visitors out. This study shows that Jordan is a developing country with huge untapped potential as a tourist destination. This research highlights tourism in Jordan and identifies impediments to tourism development. This study shows that Jordan is a developing country with huge untapped potential as a tourist destination. This research highlights tourism in Jordan and identifies obstacles to tourism development by studying the perceptions of stakeholders in the field of tourism in Jordan, as well as the views of 
local communities and tourists to the country. The results indicate that the lack of funding for the tourism market in Jordan effectively hinders development and growth, as well as the lack of knowledge about the intrinsic value of archaeological sites and the lack of facilities in popular tourist destinations. These are the important impediments that must be overcome, as they not only impede the development of tourism but also economic growth in Jordan. Previous research points to some obstacles, but no research has yet been conducted about gauge the perceptions of stakeholders in the field of tourism regarding these impediments.

The Cobneah, Black \& Thwaites (2012) aimed at identifying tourism planning in developing countries: a review of concepts and sustainability issues and exploring how the historical development of tourism and sustainability issues have informed the status of tourism activities in developing countries by Using secondary data analysis, also it reveals that current conceptual interpretations of tourism are linked to sustainable development. However, tourism activities in developing countries are usually profitable without adequate consideration of environmental and social factors. The paper discusses two questions and recommends that tourism activities be based on the principles of sustainable development. The paper explored the theoretical foundations of tourism and its potential to contribute to sustainable development in developing countries. In addition; the study confirmed that the current discussions on tourism have focused on achieving sustainable development. It also indicates to the emergence of sustainable forms and approaches to tourism development, including ecotourism, community tourism and pro-poor tourism. Accordingly, the study noted that while these alternative forms of sustainable tourism are available as concepts, they are not applied in many developing countries because of the increasing foreign domination and lack of effective tourism policies, as well as the lack of a precise interpretation of the concept of tourism sustainability. It also revealed that very few benefits are realized by local communities, because of foreign domination and profit-oriented institutions. However, the paper showed that many developing countries, particularly in Africa, lack effective policies that support community participation in tourism activities, leading to marginalization of communities, worsening poverty and increased reliance on the natural environment, this situation threatens sustainable development efforts in developing countries.

The Krutwaysho study (2003) aimed at identifying obstacles to the implementation of tourism policies and regulations in Phuket, Thailand. Tourism policy has become increasingly vital for many developing countries that wish to use tourism for their regional and national development. To ensure its effectiveness, it depends on the policy implementation process, which is often a major obstacle to success.

\section{What distinguishes the current study from previous studies?}

The study examined tourism planning and impediments to the development and development of the tourism sector in Jordan, where the study agreed with some previous studies in determining the independent variables of tourism planning, such as (Bjawia, 2015) (Hormuz, 2006)(Ajaj, 2007) and (Hammad, 2011). The study relied on the questionnaire to collect data and test hypotheses.

\section{Methodology and procedures}

\subsection{Methodology of the study}

The descriptive analytical approach was used and a questionnaire was prepared to collect data after verifying their validity and stability because of its appropriateness in achieving the objectives of this study to identify tourism planning in Jordan and the impediment to development of the tourism sector.

\subsection{Population of the study}

The study population consists of all employees (males/femals) of the tourism sector (public and private) in Jordan.

\subsection{The study sample}

The study sample consisted of 500 employees (male/female) of the tourism sector (public and private) in Jordan. Table (1) shows the distribution of the study samples according to the following variables (gender, sector, years of service, occupational category, educational qualification, monthly income):

\begin{tabular}{|c|c|c|}
\hline \multicolumn{3}{|c|}{ Table (1) Distribution of study sample by gender } \\
\begin{tabular}{|c|c|c|}
\hline Gender & Frequency & \% \\
\hline Male & 2017 & $53.0 \%$ \\
\hline Female & 283 & $56.6 \%$ \\
\hline Total & 500 & $100 \%$ \\
\hline
\end{tabular}
\end{tabular}

Table (1) shows Distribution of study sample by gender: The frequency of males was 217 and $43.0 \%$, while female frequency was 283 and percentage was $56.6 \%$. 


\begin{tabular}{|} 
Table (2) Distribution of study sample by sector \\
\begin{tabular}{|c|c|c|}
\hline Sector & Frequency & \% \\
\hline Public & 250 & $50 \%$ \\
\hline Private & 250 & $50 \%$ \\
\hline Total & 500 & $100 \%$ \\
\hline
\end{tabular}
\end{tabular}

Table (2) shows Distribution of study sample by sector: The frequency of the public sector was 250 and $\% 50.0$. While the privet sector frequency was 250 and $\% 50.0$.

Table (3) Distribution of study sample by years of service

\begin{tabular}{|c|c|c|}
\hline Years of service & Frequency & \% \\
\hline Less than 5 years & 247 & $49.4 \%$ \\
\hline 5-6 years & 218 & $43.6 \%$ \\
\hline 15-20 years & 24 & $4.8 \%$ \\
\hline More than 20 years & 11 & $2.2 \%$ \\
\hline Total & 500 & 100.0 \\
\hline
\end{tabular}

Table (3) shows the distribution of study sample by years of service: The frequency of the sample who responded "less than 5 years" (247) and (49.4\%), while frequency of the sample who responded "5-10 years" (218) and $43.6 \%$.as for the frequency for whom responded " $20-20$ years" (24) and $(4.8 \%)$.

Table (4) Distribution of study sample by occupational category

\begin{tabular}{|c|c|c|}
\hline occupational category & Frequency & \% \\
\hline First & 188 & 37.6 \\
\hline Second & 219 & 43.8 \\
\hline Third & 93 & 18.6 \\
\hline Total & 500 & 100.0 \\
\hline
\end{tabular}

Table (4) shows the distribution of study sample by occupational category: The frequency of the sample who responded "first" (188) and (37.6\%). The frequency of the sample who answered "second" (219) and (43.8\%), the frequency of the sample of respondents "third" (93) and (18.6\%)

Table (5) Distribution of study sample by educational qualification

\begin{tabular}{|c|c|c|}
\hline Educational qualification & Frequency & \% \\
\hline Diploma -PG & 155 & 31.0 \\
\hline BA & 301 & 60.2 \\
\hline Postgraduate & 44 & 8.8 \\
\hline Total & 500 & 100.0 \\
\hline
\end{tabular}

Table (5) shows distribution of study sample by educational qualification: the frequency of the sample who responded "PG" (155) and (31.0\%), while the frequency of the sample who responded "Bachelor" (301)and $(60.2 \%)$, and the frequency of the sample who answered "postgraduate studies" (44) and (8.8\%).

Table (6) Distribution of study sample by monthly income

\begin{tabular}{|c|c|c|}
\hline Monthly income & Frequency & \% \\
\hline Less than 500 & 168 & 33.6 \\
\hline $500-1000$ & 145 & 29.0 \\
\hline $1001-1500$ & 115 & 23.0 \\
\hline More than 1500 & 72 & 14.4 \\
\hline Total & 500 & 100.0 \\
\hline
\end{tabular}

Table (6) Distribution of study sample by monthly income: the frequency of the sample who responded "less than 500) (168) and (33.6\%), while the frequency of the sample who responded (500-1000) (145) and (29.0\%). As for the frecuancy of the sample who responded (1001-1500) (115) and (23.0\%). The frequency of the responded (more than 1500) (27) and (14.4)

\subsection{Tools of the Study tool}

A questionnaire was constructed to collect data from the study sample by using previous studies (Othman, 2017; Bajawia, 2015; Bahammam, 2006). The final form was composed of two parts as follows:

- The first part included the demographic variables of the sample of the study (gender, sector, years of service, job category, educational qualification, and monthly income).

- The second part: It included two areas, namely:

- The first area: the level of tourism planning, which includes (15) items that measures the level of tourism planning in Jordan.

- $\quad$ The second area is the impediments to the development of the tourism sector in Jordan. It included (25) items that measure the impediments to the development of the tourism sector in Jordan and divided into 
five areas. Each area includes (5) items :

1. Impediments of service development.

2. Impediments of organizational, administrative and information development

3. Impediments of social development.

4. Impediments of political development.

\subsection{Validity of the Study}

In order to verify the validity of the study tool, the researcher adopted the method of verifying the content. The researcher presented the study tool in its preliminary form to a group of (8) arbitrators who are specialized in tourism field. The researcher asked the arbitrators to make their observations and opinions on the validity of these items, for which they were prepared, the appropriateness of each items of the field in which they were placed, and the addition or deletion of any items they find them appropriate. The linguistic formulations proposed by the arbitrators have been amended.

\subsection{Reliability of the study}

In order to ensure the reliability of the study instrument, the test-retest was verified by applying the scale to a group of (500) employees in the tourism sector (public and private). Therefore, Pearson correlation coefficient was calculated as shown in Table(7)

Table( 7) Kronbach Alpha coefficients for the level of tourism planning and areas of study

\begin{tabular}{|l|c|c|}
\hline \multicolumn{1}{|c|}{ Item } & Kronbach & \multicolumn{1}{|c|}{$\begin{array}{c}\text { Retest } \\
\text { reliability }\end{array}$} \\
\hline 1. Impediments of service development. & 91.0 & 92.0 \\
\hline $\begin{array}{l}\text { 3. Impediments of organizational, administrative and information } \\
\text { development }\end{array}$ & 83.0 & 93.0 \\
\hline 4. Impediments of social development. & 87.0 & 85.0 \\
\hline 5. Impediments of political development. & 95.0 & 96.0 \\
\hline $\begin{array}{l}\text { 1. Impediments of service development. } \\
\text { 3. Impediments of organizational, administrative and information } \\
\text { development }\end{array}$ & 88.0 & 96.0 \\
\hline Total & 95.0 & 84.0 \\
\hline
\end{tabular}

Table (7) shows that internal consistency coefficients ranged between $0.83-0.95$, the most prominent was the "organizational, administrative and media development obstacles". The lowest "service development obstacles" while Kronbach's alpha coefficient were (0.95).

\subsection{Correcting scale}

The scale consists of (40) items, with Five Likert scale grads from (1-5) as follows:

Less than (2.34) low score.

From (2.34-3.66) middle score.

More than (3.66) high score.

\subsection{Variables of the study:}

- Independent variables:

Gender, sector, years of service, occupational category, educational qualification, monthly income

- Dependent variables

- The level of tourism planning in Jordan.

- Impediment to the development of the tourism sector in Jordan in the fields of service, environment, organizational, administrative, media, social and political.

\subsection{Statistical method}

To answer the study questions, the following statistical analyses were used through the Statistical Package Program (SPSS):

1. Calculating the frequencies and percentages of the personal variables of the study sample.

2. Apply the Kronbach alpha formula to find the internal consistency.

3. Calculating the averages and standard deviations for all fields of study and the general average

\section{Findings}

The results of the study questions which are presented according to the following variables ( Gender, sector, years of service, occupational category, educational qualification, monthly income ) as follows : 
The first question: what is the level of planning in Jordanian tourism sector? To answer this question, the averages and standard deviations were used for the level of planning in Jordanian tourism sector. As shown in Table (8)

Table (8) the means and standard deviations

\begin{tabular}{|c|l|c|c|c|c|}
\hline No & Domain & Mean & $\begin{array}{c}\text { Standard } \\
\text { deviation }\end{array}$ & Rank & Level \\
\hline 1 & level of tourism planning & 3.47 & 0.64 & 5 & Medium \\
\hline 2 & Impediments of service development. & 3.56 & 0.59 & 4 & Medium \\
\hline 3 & Impediments of environmental development & 3.67 & 0.67 & 2 & Medium \\
\hline 4 & $\begin{array}{l}\text { Impediments of organizational, } \\
\text { administrative and information development }\end{array}$ & 3.77 & 0.67 & 1 & Medium \\
\hline 5 & Impediments of social development. & 3.59 & 0.74 & 3 & Medium \\
\hline 6 & Impediments of political development. & 3.36 & 0.76 & 6 & Medium \\
\hline \multicolumn{2}{|l|}{ General mean } & 3.55 & 0.47 & & Medium \\
\hline
\end{tabular}

Table (8) shows the means and the standard deviations. The most prominent of these were the "organizational, administrative and media development impediment s" with mean of (3.77). While "environmental development impediments" ranked second, with mean of (3.67) and a high score. As for the "social development impediments" ranked third with an average of (3.59) and a medium degree, the level of tourism planning was ranked fifth with mean of (3.47) and a medium level. While "political obstacles" came last with an mean of (3.36) and to a medium degree. The overall mean of the instrument as a whole (3.55) was medium. This is due to:

Scale of the level of Tourist Planning:

Table (9) means and standard deviations of the level of tourism planning

\begin{tabular}{|c|c|c|c|c|c|}
\hline No & Domain & mean & $\begin{array}{l}\text { Standard } \\
\text { deviation }\end{array}$ & Rank & Level \\
\hline 1 & There is an analysis of all tourism activities & 3.29 & 1.17 & 15 & Medium \\
\hline 2 & $\begin{array}{l}\text { Tourism planning was used to organize public services } \\
\text { for tourist sites }\end{array}$ & 3.32 & 1.22 & 14 & Medium \\
\hline 3 & $\begin{array}{l}\text { Tourism planning is used to develop resources and } \\
\text { tourism components }\end{array}$ & 3.59 & 1.26 & 2 & Medium \\
\hline 4 & $\begin{array}{l}\text { Statistical indicators are available on all aspects of } \\
\text { tourism }\end{array}$ & 3.56 & 1.28 & 4 & Medium \\
\hline 5 & $\begin{array}{l}\text { Plans are reviewed from time to time according to } \\
\text { circumstances and developments }\end{array}$ & 3.35 & 0.98 & 13 & Medium \\
\hline 6 & There are annual and quarterly plans to stimulate tourism & 3.40 & 1.08 & 11 & Medium \\
\hline 7 & The touristic planning is used to prioritize priorities & 3.45 & 1.21 & 8 & Medium \\
\hline 8 & Tourist planning is used to implement policies clearly & 3.81 & 1.30 & 1 & Medium \\
\hline 9 & $\begin{array}{l}\text { Tourist planning is used to provide information that } \\
\text { depends on tourism development }\end{array}$ & 3.58 & 1.21 & 3 & Medium \\
\hline 10 & $\begin{array}{l}\text { Tourist planning is used to prepare tourism development } \\
\text { plans }\end{array}$ & 3.54 & 1.27 & 5 & Medium \\
\hline 11 & $\begin{array}{l}\text { Tourist planning is used to spread the culture of tourism } \\
\text { development }\end{array}$ & 3.43 & 1.08 & 9 & Medium \\
\hline 12 & $\begin{array}{l}\text { Tourist planning is used to exploit resources and } \\
\text { potentials }\end{array}$ & 3.41 & 1.07 & 10 & Medium \\
\hline 13 & $\begin{array}{l}\text { Tourist planning is used to encourage researchers and } \\
\text { scholars to study and develop tourism }\end{array}$ & 3.49 & 1.10 & 6 & Medium \\
\hline 14 & $\begin{array}{l}\text { Tourist planning is used to achieve integration in tourism } \\
\text { development }\end{array}$ & 3.39 & 1.26 & 12 & Medium \\
\hline 15 & $\begin{array}{l}\text { Tourist planning is used for the continuity of tourism } \\
\text { development correction }\end{array}$ & 3.47 & 1.25 & 12 & Medium \\
\hline
\end{tabular}

Table (9) shows that the meanss ranged between (3.29-3.59). Paragraph (8) which states that "Tourist planning is used to implement policies clearly. " In the first place with an mean of (3.81), while paragraph (1), which states that " There is an

analysis of all tourism activities" at the last rank and mean of (3.29).

This finding was in line with the result of the Bahammam (2006), who indicated the need to link coastal and inland areas in terms of tourism and planning to take advantage of these landmarks and attractions in the present and future.

The second question: What are the impediments to development (service, environmental, organizational, 
administrative, media, social and political) to develop the tourism sector in Jordan?

To answer this question, the averages and standard deviations of the scale of development impediments. As shown in Table (10)

First: impediments of services development

Table (10) means and standard deviations of the impediments of services development

\begin{tabular}{|c|l|c|c|c|c|}
\hline No & \multicolumn{1}{|c|}{ Domain } & Means & $\begin{array}{c}\text { Standard } \\
\text { deviation }\end{array}$ & Rank & Level \\
\hline $\mathbf{1}$ & Lack of private parking spaces for tourists & 3.52 & 1.21 & 3 & Medium \\
\hline $\mathbf{2}$ & Lack of manpower specialized in tourist services & 3.68 & 1.17 & 2 & High \\
\hline $\mathbf{3}$ & Higher transportation costs which reduce tourism & 3.43 & 0.94 & 4 & Medium \\
\hline $\mathbf{4}$ & $\begin{array}{l}\text { Lack of interest in the service methods provided, which } \\
\text { reduces tourism traffic }\end{array}$ & 3.91 & 0.90 & 1 & High \\
\hline $\mathbf{5}$ & Shortage of tourist services for arrivals to tourist areas & 3.26 & 1.02 & 5 & Medium \\
\hline
\end{tabular}

Table (10) shows that the means ranged between (3.26-3.68). Paragraph (4) which states that "Lack of interest in the service methods provided, which reduces tourism traffic. " In the first place with mean of (3.91), while paragraph (5), which states that "Shortage of tourist services for arrivals to tourist areas" at the last rank and mean of (3.26).

The results of the study agreed with the results of (Summerdly, 2013) who indicated that the lack of funding for the tourism market in Jordan effectively hinders development, the lack of knowledge about the intrinsic value of archaeological sites and the lack of facilities in popular tourist destinations. These are important obstacles that must be overcome, as they impede the development of tourism.

Second: impediments of environmental development

Table (11) mean and standard deviations of the impediments of environmental development

\begin{tabular}{|c|l|c|c|c|c|}
\hline No & \multicolumn{1}{|c|}{ Domain } & mean & $\begin{array}{c}\text { Standard } \\
\text { deviation }\end{array}$ & Rank & Level \\
\hline 1 & $\begin{array}{l}\text { The spread of pollution due to the increase in the number of } \\
\text { cars and different means of transportation }\end{array}$ & 3.29 & 1.03 & 5 & Medium \\
\hline 2 & Lack of interest in infrastructure in tourist areas & 3.68 & 1.01 & 3 & High \\
\hline 3 & $\begin{array}{l}\text { Poverty is one of the causes of environmental degradation } \\
\text { to carry out destructive practices such as overgrazing and } \\
\text { logging }\end{array}$ & 3.92 & 0.91 & 1 & High \\
\hline 4 & $\begin{array}{l}\text { Lack of interest in archaeological sites and historical and } \\
\text { religious sites }\end{array}$ & 3.80 & 0.96 & 2 & High \\
\hline 5 & $\begin{array}{l}\text { The spread of desertification is one of the most serious } \\
\text { environmental problems in Jordan }\end{array}$ & 3.67 & 1.25 & 4 & High \\
\hline
\end{tabular}

Table (11) shows that the means ranged between (3.29-3.92). Paragraph (3) which states that "Poverty is one of the causes of environmental degradation to carry out destructive practices such as overgrazing and logging. " In the first place with mean of (3.92), while paragraph (1), which states that "The spread of pollution due to the increase in the number of cars and different means of transportation" at the last rank and mean of (3.29).

This finding was consistent with Cobbinah, Black \& Thwaites (2012), who showed that tourism activities in developing countries are usually profit-driven without adequate consideration of environmental and social factors.

Third: the impediments of organizational, administrative and information development

Table (12) means and standard deviations of the impediments of environmental development

\begin{tabular}{|c|l|c|c|c|c|}
\hline No & \multicolumn{1}{|c|}{ Domain } & Means & $\begin{array}{l}\text { Standard } \\
\text { deviation }\end{array}$ & Rank & Level \\
\hline 1 & Lack of laws for tourism work & 3.70 & 1.27 & 4 & High \\
\hline 2 & $\begin{array}{l}\text { Lack of full coordination between tourism agencies and } \\
\text { institutions }\end{array}$ & 3.87 & 0.98 & 2 & High \\
\hline 3 & $\begin{array}{l}\text { Lack of some leisure projects when tourism facilities } \\
\text { attract tourists and families }\end{array}$ & 3.90 & 0.97 & 1 & High \\
\hline 4 & $\begin{array}{l}\text { Lack of information and communication tools on } \\
\text { tourism activity }\end{array}$ & 3.86 & 0.98 & 3 & High \\
\hline 5 & Weakness of technology and media in tourism & 3.51 & 1.06 & 5 & Medium \\
\hline
\end{tabular}

Table (12) shows that the means ranged between (3.51-3.90). Paragraph (3) which states that "Lack of some leisure projects when tourism facilities attract tourists and families" In the first place with an average of (3.90), while paragraph (5), which states that "Weakness of technology and media in tourism" at the last rank and mean of (3.51).

This result was agreed with (Hammad, 2011), which showed the lack of role played by the various media to 
develop tourism awareness among members of the Palestinian society.

Fourth: Impediments of social development

Table (13) means and standard deviations of the impediments of social development

\begin{tabular}{|c|l|c|c|c|c|}
\hline No & \multicolumn{1}{|c|}{ Domain } & Means & $\begin{array}{c}\text { Standard } \\
\text { deviation }\end{array}$ & Rank & Level \\
\hline 1 & Customs and traditions affect tourism & 3.85 & 1.01 & 1 & High \\
\hline 2 & $\begin{array}{l}\text { The spread of the phenomenon of irritations in tourist } \\
\text { places }\end{array}$ & 3.55 & 1.08 & 4 & Medium \\
\hline 3 & Weakness in tourism guidance & 3.25 & 1.17 & 5 & Medium \\
\hline 4 & Lack of internal tourism programs & 3.57 & 1.29 & 3 & Medium \\
\hline 5 & Lack of social awareness of the importance of tourism & 3.73 & 1.25 & 2 & High \\
\hline
\end{tabular}

Table (13) shows that the means ranged between (3.25-3.85) .Paragraph (1) which states that "Customs and traditions affect tourism" In the first place with means of (3.85), while paragraph (3), which states that "Weakness in tourism guidance "at the last rank and mean of (3.25).

This finding was consistent with the result of (Cobbinah, Black \& Thwaites, 2012), who showed that many developing countries, particularly in Africa, lack effective policies to support community participation in tourism activities.

Fifth: Impediments of political development.

Table (14) means and standard deviations of the impediments of social development

\begin{tabular}{|c|l|c|c|c|c|}
\hline No & \multicolumn{1}{|c|}{ Domain } & Means & $\begin{array}{l}\text { Standard } \\
\text { deviation }\end{array}$ & Rank & Level \\
\hline 1 & lack of security aspects in tourist places on tourism & 3.35 & 1.12 & 4 & Medium \\
\hline 2 & $\begin{array}{l}\text { The spread of the phenomenon of irritations in tourist } \\
\text { places The low level of political and government } \\
\text { support for the tourism sector }\end{array}$ & 3.28 & 1.12 & 5 & Medium \\
\hline 3 & Poor handling of domestic and foreign tourists & 3.44 & 1.20 & 1 & Medium \\
\hline 4 & Lack of governmental coordination between the parties & 3.36 & 1.12 & 3 & Medium \\
\hline 5 & Lack of strategic evaluation of tourism projects & 3.39 & 1.05 & 2 & Medium \\
\hline
\end{tabular}

Table (14) shows that the means ranged between (3.28-3.44) .Paragraph (3) which states that "Poor handling of domestic and foreign tourists" In the first place with mean of (3.44), while paragraph (2), which states that "The spread of the phenomenon of irritations in tourist places The low level of political and government support for the tourism sector "at the last rank and an means of (3.28).

\section{Recommendations}

In the light of the previous results, the researcher recommends the following:

1. 1.The necessity of the Ministry of Tourism to analyze all tourism activities and to reach results that will help in making decisions when making tourism development plans.

2. The necessity of the Ministry of Tourism to activate the development of strategic plans to organize tourism work and review plans prepared in advance and adapt them according to current developments and conditions of the current era.

3. The importance of developing tourist services and keeping abreast of developments in the field of tourism services.

4. The need to organize plans and procedures for the preservation of the environment and the activation of penalties for those who attack them.

5. The need to encourage domestic and foreign investment in tourism and leisure projects.

6. The need to use various media to educate the community about the importance of tourism.

\section{References}

- Jenkins, C. L. (1994). Tourism in developing countries: the privatisation issue. UK: Tourism: The State of the Art, John Wiley \& Sons, Chichester, 3-9. https://www.researchgate.net/publication/265099936_Privatization_in_Developing_Countries_Formal_ Causes_Critical_Reasons_and_Adverse_Impacts

- Cobbinah, P. B., Black, R., \& Thwaites, R. (2013). Tourism planning in developing countries: review of concepts and sustainability issues. International Journal of Economics and Management Engineering, 7 (4), 34-41. http://waset.org/publications/9997066/Tourism-Planning-in-Developing-Countries:-Reviewof-Concepts-and-Sustainability-Issues.

- Samardali, L. (2013). Obstacles which significantly affect tourism development in Jordan. Master Thesis, Edith Cowan University, $\quad$ Western Australia. 
https://www.researchgate.net/publication/307241576_Urban_Tourism_in_Jordan_Challenges_and_Op portunities_Case_Study_Amman

- Krutwaysho, M. O. (2003). Obstacles to the implementation of tourism policies and regulations in Phuket, Thailand. In 12th International Tourism and Leisure Symposium, Barcelona, Spain. Retrieved from http://www. esade. es/cedit2003/pdfs/krut wayshooratai. pdf.

- Ahmed, Manal (2011). The fundamentals of tourism planning. Alexandria, Egypt: Dar El Wafaa for Printing and Publishing. http://gwweb.jica.go.jp/km/FSubject1101.nsf/3b8a2d403517ae4549256f2d002e1dcc/accd52c56b985c8 b49256fa200062965/\$FILE/\%E3\%82\%A8\%E3\%82\%B8\%E3\%83\%97\%E3\%83\%88\%E8\%8B\%B12b.pdf

- Bjuba, seham (2015). Tourism planning as a tool to achieve tourism development A pilot study of the experience of Tunisia - the shadow of Algeria. Unpublished MA thesis, University of Amahab and Boumerdes, Algeria. http://www.academia.edu/15541186/A_prospective_analysis_of_sustainable_tourism_in_Tunisia_using scenario_method

- Ibrahim (2012). Ecotourism between theory and practice (i 1). Amman: Al Warraq Publishing \& Distribution Est.

- Al- Jallad, Ahmed (2002). Continuing eco-tourism (i 1). Egypt: Book Worker.

- Jalila, Hassanein (2000). Tourism Economics. Alexandria: University House.

- Hammad, Abdelkader (2013). The Impact of Tourism on Urbanization in the Gaza Strip, Journal of the Humanities Studies Sector, Al-Azhar University, (8).

- Dulaimi, Sufian Munther (2005). The Impact of Tourism Development Planning on Social and Economic Life in Northern Iraq, Master Thesis (unpublished), Center for Urban and Regional Planning, University of Baghdad, Iraq.

- Diab, Mohammed (2015). Tourism development and fiscal and monetary policies (i). Amman, Jordan: Dar Al Ayam for Publishing and Distribution.

- Rashid, Hanan Fadl (2003). Tourism Obstacles in Jebel Marra, Unpublished Master Thesis, University of Khartoum, Sudan.

- Saad, Mohiuddin (2008). Recent trends in tourism. Alexandria, Egypt: Modern University Office. https://www.researchgate.net/publication/228471146_Internet_Developments_in_the_Egyptian_Touris m_Industry

- Salman, Jamal Daoud (2002). Economic planning. Iraq: House of books for printing and publishing.

- Osman, Kamal al-Din (2017). Tourism Planning as a tool for the development of archaeological and religious tourism in the city of Samarra, Al-Malawiya Journal of Archaeological and Historical Studies, 4 (7). https://pdfs.semanticscholar.org/6217/cd6ac68a5b38e18734012e5ab796b91bb60a.pdf

- Antar, Mohammed (2006). Obstacles of Tourism Activity and its Implications for Economic Development in Sudan, Unpublished Master Thesis, University of Khartoum, Sudan.

- Ghunaim, Mohamed Othman (2004). Tourism planning and tourism development. Cairo: Egyptian Renaissance.

- Qasymh, Kabbashi (2010). Tourism Planning and its Impact on Areas and Sites of Archaeological Heritage, Shandi University Journal, (9), 127.

- Mustafa, Khater Ahmed (2005). Community development. Alexandria, Egypt: Modern University Office. 